\title{
Comments on 'Area changes of glaciers on active volcanoes in Latin America' by Reinthaler and others (2019)
}

\section{Communication}

Cite this article: Kochtitzky W, Edwards B (2020). Comments on 'Area changes of glaciers on active volcanoes in Latin America' by Reinthaler and others (2019). Journal of Glaciology 66(257), 520-522. https://doi.org/ $10.1017 /$ jog.2020.25

Received: 26 November 2019

Revised: 18 March 2020

Accepted: 19 March 2020

First published online: 22 April 2020

Author for correspondence:

William Kochtitzky, E-mail: will.kochtitzky@ uottawa.ca

\section{William Kochtitzky ${ }^{1}$ (I) and Benjamin Edwards ${ }^{2}$}

${ }^{1}$ Department of Geography, Environment and Geomatics, University of Ottawa, Ottawa, ON, Canada and ${ }^{2}$ Department of Earth Sciences, Dickinson College, Carlisle, PA, USA

Reinthaler and others (2019), hereafter Reinthaler 2019, characterize ice extent on 59 volcanoes in Latin America from 1986 to 2015 using Landsat and Sentinel-2 imagery to quantify the impact of climate and eruptions on glacier evolution. Here we compare the work of Reinthaler 2019 with Kochtitzky and others (2018), hereafter Kochtitzky 2018, on Nevado Coropuna Ice Cap, and present some new analysis to highlight the challenges of seasonal snow coverage in the delineation of glaciers (Pfeffer and others, 2014; Paul and others, 2017). Nevado Coropuna Ice Cap has received significant attention (e.g. Racoviteanu and others, 2007; Silverio and Jaquet, 2012; Veettil and others, 2016; Kochtitzky and others, 2018; Reinthaler and others, 2019) and is a sentinel for climate change as the biggest ice body in the tropics, in addition to being important for regional water resources for $\sim 110$ 000 residents downstream (Kochtitzky and others, 2018). However, few studies were able to avoid including transient snow cover in glacier delineations leading to overestimations of ice extent at Nevado Coropuna Ice Cap by as much as 150\% (Kochtitzky and others, 2018). This is particularly problematic because overestimation of glacier area, particularly in early years of the satellite record, can lead to erroneous glacier retreat rates. Overestimating glacier retreat rates could one, be mistakenly interpreted as caused by an increase in volcanic activity and two, falsely suggest water resources could run dry sooner than is likely.

Kochtitzky 2018 show that Nevado Coropuna Ice Cap lost $0.408 \mathrm{~km}^{2} \mathrm{a}^{-1}\left(0.71 \% \mathrm{a}^{-1}\right)$ of ice from 1980 to 2014 with almost annual ice area estimates and examination of 259 individual Landsat scenes. This is in contrast to Reinthaler 2019 who estimate Nevado Coropuna Ice Cap ice loss at $0.52 \mathrm{~km}^{2} \mathrm{a}^{-1}\left(0.86 \% \mathrm{a}^{-1}\right)$ from 1986 to 2016 with three Landsat scenes. To understand why these apparent differences exist we applied the Kochtitzky 2018 and Reinthaler 2019 methodologies to all relevant imagery (Fig. 1; Table 1). Reinthaler 2019 finds a $42 \%$ greater annual percent change at Nevado Coropuna Ice Cap than Kochtitzky 2018 over similar time frames (Table 1). To reproduce Reinthaler 2019 we used a threshold of 2.0 (the maximum value in their range of 1.6-2.0 for Landsat 4,5 and 7 imagery) in their NIR/SWIR ratio to get the smallest area within their stated threshold range. To reproduce Kochtitzky 2018 we used their threshold of 0.5567 in the normalized difference snow index. We find that both methods yield snow and ice area estimates within an average of $3.4 \%$ of each other, with a maximum $5.3 \%$ difference (Table 1 ). This difference is within the uncertainties that both studies report.

We reconstructed the Reinthaler 2019 analysis and find that they overestimated glacier area on 24 November 1986 by $15 \%\left(8 \mathrm{~km}^{2}\right.$; Fig. 1a) compared to a 5 December 1987 Landsat 4 image (Fig. 1d). This difference is outside the 5.7\% uncertainty Reinthaler 2019 cite as the average for glaciers delineated in 1986 and the maximum $8.3 \%$ uncertainty cited by Kochtitzky 2018. While rapid ice loss due to melting, ice dynamics or a volcanic event is possible, we find that the $15 \%$ area difference in one year is due to snow cover (Figs 1a, d).

We find the ice cap outline from a 2000 Landsat 5 image chosen by Reinthaler 2019 (Fig. 1b) to be 15\% larger than Kochtitzky 2018's outline of a 1998 Landsat 5 image (Figs 1b, e) again due to snow cover. The 2016 image chosen by Reinthaler 2019 shows clouds obscuring portions of the glacier margin rendering it inappropriate for analysis (Fig. 1c). However, Reinthaler 2019 and Kochtitzky 2018 are in good agreement with the recent areal extents of $44.7 \mathrm{~km}^{2}$ in 2016 and $44.1 \mathrm{~km}^{2}$ in 2014 , respectively.

The difference between early imagery of Nevado Coropuna Ice Cap selected by Reinthaler 2019 and Kochtitzky 2018 is transient snow cover obscuring the glacier margin (Fig. 1). We conclude that mapping methods used by Kochtitzky 2018 and Reinthaler 2019 are both appropriate for Nevado Coropuna Ice Cap mapping; however, differences in reported glacier retreat rates are due to transient snow cover in satellite imagery, and not due to glacier change. The ice loss rate of $-0.408 \mathrm{~km}^{2} \mathrm{a}^{-1}\left(0.71 \% \mathrm{a}^{-1}\right)$ from 1980 to 2014 presented by Kochtitzky 2018 is more accurate for Nevado Coropuna Ice Cap.

We also examined imagery from Nevado del Huila, Colombia, where Reinthaler 2019 report a $44.7 \%$ loss of ice from $16.000 \mathrm{~km}^{2}$ (Landsat 5 on 14 January 1987) to $8.847 \mathrm{~km}^{2}$ (Landsat 8 on 14 January 2016) in 29 years. Because the glaciers in the 14 January 1987 Landsat 5 image they chose are partially obscured by a cloud, we reconstructed their analysis in a 23 October, 1988 image. While this image is partially covered in snow and/or small clouds, we still found a maximum area of $15.3 \mathrm{~km}^{2}$ (including most snow and clouds) using their NIR/SWIR ratio with a 2.0 


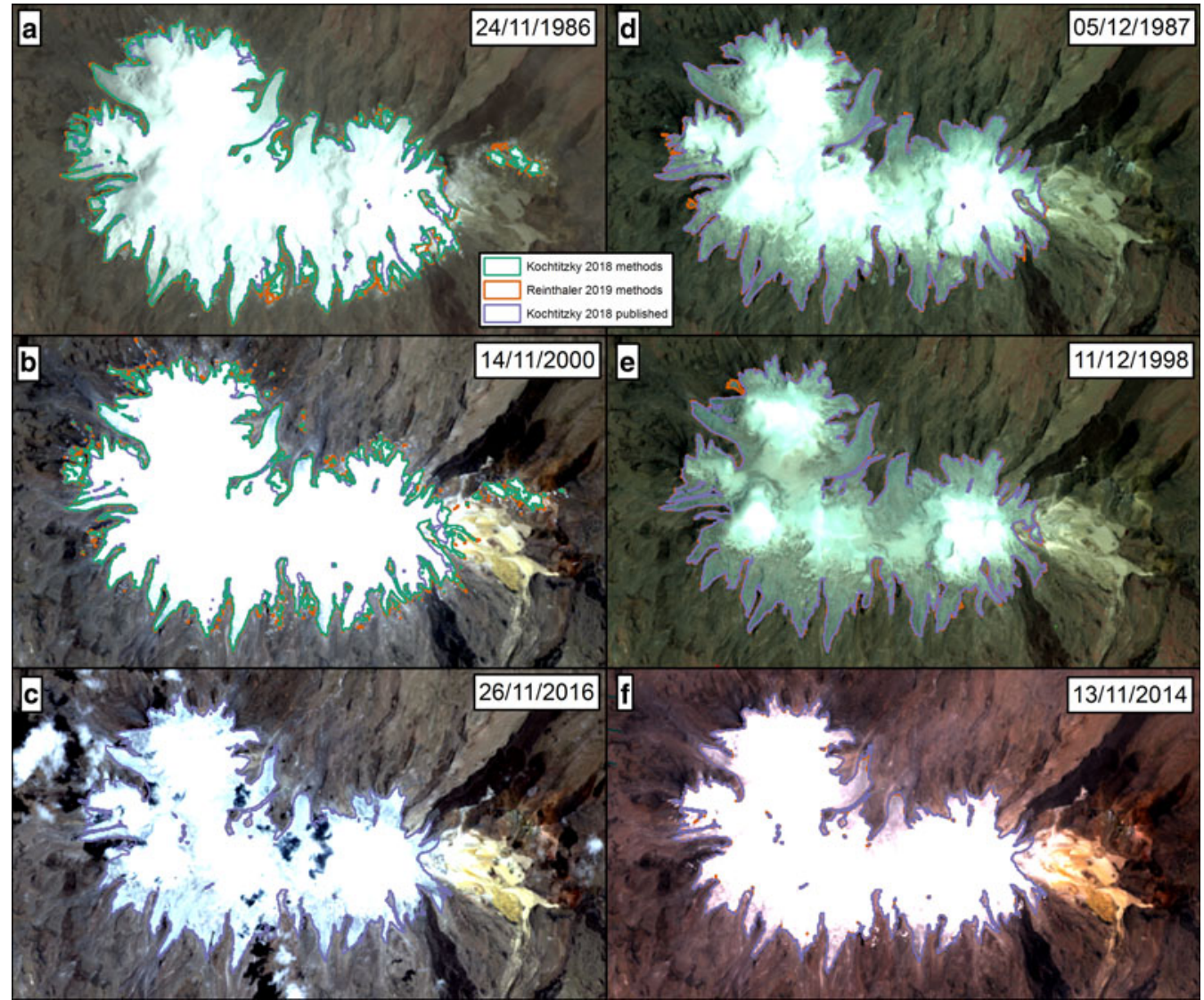

Fig. 1. Change of Nevado Coropuna Ice Cap. (a-c) Images used in ice cap change analysis presented by Reinthaler 2019 with outlines of each image using methods from Kochtitzky 2019 (green; top layer), Reinthaler 2019 (orange; middle layer) and the outline published by Kochtitzky 2018 (bottom layer) for a temporally nearby year with less snow cover shown in the subplot to the right. (d-f) Icecap changes presented by Kochtitzky and others (2018; purple; top layer) with an outline using the Reinthaler 2019 methodology in orange (bottom layer).

Table 1. Area changes of Nevado Coropuna Ice Cap

\begin{tabular}{|c|c|c|c|c|c|c|}
\hline Date & $\begin{array}{c}\text { Area }\left(\mathrm{km}^{2}\right) \text { Reinthaler } \\
\text { published }\end{array}$ & $\begin{array}{l}\text { Area }(\mathrm{km} 2) \text { Kochtitzky } \\
2018 \text { method }\end{array}$ & $\begin{array}{c}\text { Area }\left(\mathrm{km}^{2}\right) \text { Reinthaler } \\
2019 \text { method }\end{array}$ & Date & $\begin{array}{c}\text { Area }\left(\mathrm{km}^{2}\right) \text { Kochtitzky } \\
2018 \text { published }\end{array}$ & $\begin{array}{c}\text { Area }\left(\mathrm{km}^{2}\right) \text { Reinthaler } \\
2019 \text { method }\end{array}$ \\
\hline $24 / 11 / 86$ & 60.9 & 57.0 & 60.0 & $5 / 12 / 87$ & 52.9 & 54.3 \\
\hline $14 / 11 / 00$ & 55.2 & 52.4 & 54.8 & $11 / 12 / 98$ & 48.0 & 49.3 \\
\hline $26 / 11 / 16$ & 44.7 & - & - & $13 / 11 / 14$ & 44.1 & 43.3 \\
\hline $\begin{array}{l}\text { Area change (first } \\
\text { to last) }\end{array}$ & $-0.88 \% a^{-1}$ & & & & $-0.62 \% a^{-1}$ & \\
\hline
\end{tabular}

threshold. We completed the same analysis using the same methods as Reinthaler 2019 on the 14 January 2016 Landsat 8 image and found the ice masses had been separated by a lava dome with a 6.3 $\mathrm{km}^{2}$ ice mass to the north and $1.3 \mathrm{~km}^{2}$ ice mass to the south (lava dome formed between 2008 and 2012). We find a $1.2 \mathrm{~km}^{2}$ difference in our analyses for the same 2016 image, which we attribute to misclassification of the lava dome as ice. Consequently, we find an areal loss of 59\% between 1988 and 2016, instead of Reinthaler 2019's loss of 45\%.

Documentation of the rates of change for ice area and mass at Nevado Coropuna Ice Cap, Nevado del Huila, and other tropical glaciers needs to be completed carefully, so that scene selection is not biased by snow cover or clouds (Paul and others, 2013). While finding snow and cloud free imagery in the tropics can be extremely challenging, it is crucial for accurate analysis. Kochtitzky 2018 showed in their reconstruction of the Nevado Coropuna Ice Cap, and we re-emphasize here, that the overestimation of glacier area early in the record can lead to inflated retreat rates that are not based in reality. Where possible, we recommend cartographers use multisource and multiscale imagery to aid in the interpretation of glacier boundaries. Most importantly, we recommend that best practices in glacier mapping include careful examination of the entire image archive for cloud free imagery and the inclusion of the best available imagery, even if it is temporally far from the ideal collection time, to ensure accurate glacier maps and retreat rates calculations.

Acknowledgements. Comments by two anonymous reviewers, Dr Johannes Reinthaler, and the Scientific Editor, Dr Hester Jiskoot, strengthen this correspondence. Kochtitzky is funded by the Vanier Graduate Scholarship.

\section{References}

Kochtitzky W, Edwards B, Enderlin E, Marino J and Marinque N (2018). Improved estimates of glacier change rates at Nevado Coropuna Ice Cap, Peru. Journal of Glaciology 64(244), 175-184. doi:10.1017/jog.2018.2.

Paul F and 19 others (2013) On the accuracy of glacier outlines derived from remote-sensing data. The Annals of Glaciology 54(63), 171-182. doi:10. 3189/2013AoG63A296.

Paul F and 10 others (2017). Error sources and guidelines for quality assessment of glacier area, elevation change, and velocity products derived from 
satellite data in the Glaciers_cci project. Remote Sensing of Environment 203, 256-275. doi:10.1016/j.rse.2017.08.038.

Pfeffer WT and 18 others (2014) The Randolph Glacier Inventory: a globally complete inventory of glaciers. Journal of Glaciology 60(221), 537-552. doi:10.3189/2014JoG13J176.

Racoviteanu AE, Manley WF, Arnaud Y and Williams MW (2007) Evaluating digital elevation models for glaciologic applications; an example from Nevado Coropuna, Peruvian Andes. Global Planetary Change 59 (1-4-4), 110-125. doi: 10.1016/j. gloplacha.2006.11.036.

Reinthaler J, Paul F, Granados H, Rivera A and Huggel C (2019). Area changes of glaciers on active volcanoes in Latin America between 1986 and 2015 observed from multi-temporal satellite imagery. Journal of Glaciology 65(252), 542-556. doi:10.1017/jog.2019.30.

Silverio W and Jaquet J-M (2012) Multi-temporal and multi-source cartography of the glacial cover of Nevado Coropuna (Arequipa, Peru) between 1955 and 2003. International Journal of Remote Sensing 33(18), 58765888. doi: 10.1080/01431161.2012.676742.

Veettil BK, Bremer UF, de Souza SF, Maier ÉLB and Simões JC (2016) Variations in annual snowline and area of an ice-covered strato- volcano in the Cordillera Ampato, Peru, using remote sensing data (1986-2014). Geocarto International 31(5), 544-556. doi: 10.1080/10106049.2015. 1059902. 